\title{
Human Rights Situation in Iraq and Kurdistan Region: Constitutional and Political Prospects
}

\author{
Jaafar H. Khidir, Sarhang H. Salih \\ Faculty of Law and Political Science, Salahaddin University, Erbil, Kurdistan Region, Iraq \\ Email: jkhidir@hotmail.com, sbarzinji@yahoo.co.uk
}

Received 12 October 2014; revised 30 November 2014; accepted 13 December 2014

Copyright (C) 2014 by authors and Scientific Research Publishing Inc.

This work is licensed under the Creative Commons Attribution International License (CC BY).

http://creativecommons.org/licenses/by/4.0/

(c) (i) Open Access

\begin{abstract}
This study, which deals with Human Rights situation in Iraq and Kurdistan Region during the last three decades, aims to discuss and analyze certain Human Rights issues, including civil, political and cultural rights as stipulated in the current Iraqi Constitution and reflected under the present political circumstances, making specific short references to Human Rights Education. As a descriptive analytical study, clear integrated legal and political materials are used to draw particular realistic conclusions about violations of Human Rights, as well as the contradictions between the content of the Constitution and what is happening within political developments' process on the ground. In this regard, it seems that severe difficulties and serious challenges have reduced the capacity of Iraq and Kurdistan Region from building an efficient system for Human Rights which is able to enhance Human Rights issues and support Human Rights Education.
\end{abstract}

\section{Keywords}

Iraq, Kurdistan Region-Iraq, Human Rights, Human Rights Education, Constitutional and Political Prospects

\section{Introduction}

Although Iraq was one of the signatories of the Universal Declaration of Human Rights adopted by the UN General Assembly on 10 December 1948, the country experienced a long story regarding violations of Human Rights issues during Saddam Hussein's isolated regime, particularly in the 1980 s and 1990 s $^{1}$. Yet, until the end of the regime in 2003, there were no initiatives to increase awareness of Human Rights through any research ac-

\footnotetext{
${ }^{1}$ On December 10, 1948, 48 countries came together at the United Nations in Paris to sign the Universal Declaration of Human Rights. The complete list of these countries includes Iraq, (http://www.ohchr.org/).
} 
tivities, active learning or training. In fact, Saddam Hussein's policy was not only to violate Human Rights, but also to deprive people from their basic rights, along with the right to live; as persecution and killing became the most common feature of the regime ${ }^{2}$. While in the beginning of the 1990s Kurdistan Region-Iraq was created as a semi-independent political entity, after 2003 Human Rights issues turned to a popular slogan as a more urgent question than ever to be considered seriously; and since then Human Rights Education has become a pressing demand to be addressed officially by educational authorities, including different schools and universities in both public and private sectors ${ }^{3}$. Presently, Human Rights subject is taught as a separate module in all Iraqi schools and universities. However, as Iraq still suffers from many internal security problems, it does not seem that the country would be able to enhance Human Rights Education and make teachers, schools and even universities capable to deliver the task properly, towards promoting Human Rights Education and subsequent awareness.

Hence, it is crucial to encourage international cooperation through partnership projects with the Iraqi and Kurdistan educational institutions to support Human Rights Education process and enhance legal and political aspects of Human Rights issue; and likewise to set up special relating training courses in the country not only for students, but also for members of different governmental and nongovernmental institutions. In this direction, Salahaddin University in Erbil intends to work with a number of specialized international institutions not only to promote Human Rights culture, enhance Human Rights Education and develop a module for teaching Human Rights within schools and university curricula, but also to train a number of its academic staff on how to teach Human Rights at the university level, particularly to students of Law, Political Science and Education Faculties. For instance, three Iraqi universities, along with Salahaddin University through its Faculty of Law \& Politics, have been involved in an international partnership project with the International Human Rights Law Institute at the College of Law of the University of DePaul in Chicago, USA. This four-year project that started in 20092010, aims at supporting Human Rights, democracy and rule of law. Yet, there is an ongoing strategy by Kurdistan Regional Government (KRG) for the promotion of Human Rights that also contributes to the Human Rights awareness and empowering women.

From above points of view, this study, which deals with Human Rights situation in Iraq and Kurdistan Region during the last three decades, is important and it would be imperative for Iraqi Academics to publish relevant papers and participate in international events. Towards this direction, the study aims to discuss and analyze certain Human Rights issues, including civil, political and cultural rights and public freedoms; and then the study relates such issues to what has been stipulated in the Iraqi current Permanent Constitution of 2005, looking at the reflections of the relating international laws and constitutional principles on one hand and the current political circumstances in Iraq and Kurdistan Region on the other hand. Meanwhile, specific short references are made to Human Rights Education in the country.

As a descriptive analytical study, specific integrated legal and political materials are used to draw clear realistic conclusions about violations of Human Rights in the country, as well as the contradictions between the content of the Constitution and what is in reality happening on the ground within inevitable processes of the political developments. In this regard, it seems from the study that severe difficulties and serious challenges have reduced the capacity of Iraq and Kurdistan Region from building and developing an efficient system for Human Rights which is able to enhance Human Rights issues and support Human Rights Education and higher public awareness.

In this respect, the overall objective of the study is to tackle Human Rights situation in Iraq and Kurdistan Region to explore subsequent violations of Human Rights by the Iraqi governments, particularly under Saddam Hussein's leadership, showing how seriously most Human Rights issues have been violated. Within this general objective, the study attempts to make short references to Human Rights Education in the country during the same periods of time. Accordingly, the study divides its arguments and relating analysis into four sections to deal with the following sub-topics in relation to: 1) Human Rights' situation in Iraq before and after 2003; 2) Human Rights' issues in the current Iraqi permanent constitution; 3) Human Rights prospects under present political reality in Iraq and Kurdistan Region; and 4) Human Rights Education and related official initiatives by

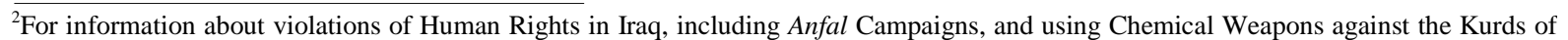
Iraq during Saddam Hussein's regime, see different annual reports and publications of: Amnesty International-Iraq, at:

http://www.amnesty.org/; and Human Rights Watch, Iraq and Kurdistan Region, at: http://www.hrw.org/; Cf. also, US Department of State, Human Rights Reports of different years, at: http://www.state.gov/www/global/human_rights/.

${ }^{3}$ For more information about Human Rights situation in Iraq after 2003, see different annual reports and publications of the United Nations Assistance Mission for Iraq (UNAMI) at: http://unami.unmissions.org/.
} 
Iraqi educational authorities. Finally, the study will be ended with further discussions, drawing specific conclusions about violations of Human Rights in Iraq and Kurdistan Region; to the extent that Iraq had during the 1980s and 1990s committed severe crimes against humanity, embracing "genocide" against the Kurdish people.

\section{Human Rights Situation before and after 2003}

The period between 1968-2003 was the most disadvantaged period in respect to Human Rights issues in Iraq, where frequent and extremely grave violations of Human Rights committed by the Iraqi totalitarian state, including its official agencies and government forces affiliated to the top Iraqi State and Arab Baath Socialist Party leaderships headed by Saddam Hussein, the President of Iraq Republic during 1980-2003. Examples of such horrible violations of Human Rights, which are vary, include withholding public liberties, individual freedoms and enormous cases of torture, arbitrary imprisonment, forced deportation, summary executions that reached ugliest crimes and repression against the Iraqi people of all ethnic groups and its components (Al-Fadhal, 2004).

This situation of repression and Human Rights' violations continued during Iran-Iraq war in the eighties of the last century, when the crimes of the Iraqi government under Saddam Hussein's regime reached to organized crimes practiced against the Kurdish people, through the following oppressiveness acts:

1) The mass killing of 8000 men from Barzani tribe in 1983;

2) Attacking the Kurdish areas of Halabja, Balisan, and Behdinan with Chemical weapons in 1988, causing the death of a large number of civilians;

3) In 1987-1988, through the so called Anfal campaign that also involved mass executions, and deportations, an estimated of 180,000 innocent Kurdish men, women and children were killed and/or disappeared by Saddam Hussein's Armed Forces ${ }^{4}$;

4) This is in addition to the displacement hundreds of thousands of Kurdish civilians from their homes and destruction of more than 4500 Kurdish village that represents more than $90 \%$ of rural areas of Kurdistan-Iraq; and

5) Finally, some of these crimes were extended to include other parts of Iraq, particularly the Faily Kurds in Baghdad and other Iraqi cities in the 1980s as well as the Shia people after their uprising in February $1990^{5}$.

As the Research Professor of Law Emeritus at DePaul University (Bassiouni, M. Charif) points out (Bassiouni, 2004), Iraq used against Iranians and Kurdish people the poison gases, which are internationally banned under the 1925 (Geneva) Protocol for the Prohibition of the Use in War of Asphyxiating, Poisonous or Other Gases, and of Bacteriological Methods of Warfare ${ }^{6}$. Similarly, the use of poison or poisoned weapons is also forbidden by item (a) of article (23) of the Hague Convention of $1907^{7}$. In this connection, Professor (Bassiouni, 2004: 16-22) classifies the crimes that were committed by the Iraqi regime under Saddam Hussein and Ba'ath leadership, into two categories:

Firstly, Crimes committed against the people of Iraq that included killing of more than 300,000 civilians without any legal justification and this number represents $6 \%$ of the total number of adult population of Iraq. These large crimes, which include torture, detention, displacement, confiscation of properties, deprivation from the citizenship and even rape, were not only against the Iraqi laws, but also exceeded all international standards for the protection of Human Rights and in particular articles 1, 2, 4, 5 of the Convention against Torture and Other Cruel, Inhuman or Degrading Treatment or Punishment of $1984^{8}$, articles 6, 7, 27 of the International

\footnotetext{
${ }^{4}$ About the Anfal Campaigns, see for example: Human Rights Watch-HRW (1993) Genocide in Iraq: The Anfal Campaign against the Kurds, Published by Human Rights Watch, at: http://www.unhcr.org/refworld/docid/47fdfb1d0.html, accessed on $27^{\text {th }}$ January 2013. Cf. also: http://www.hrw.org/reports/2006/08/14/genocide-iraq-anfal-campaign-against-kurds.

${ }^{5}$ See also other related reports, for example: SADDAM HUSSEIN: Crimes and Human Rights Abuses, A report on the human cost of Saddam's policies, Produced for the Foreign \& Commonwealth Office, issued in November 2002 in UK.

${ }^{6}$ The Geneva Protocol of 1925, which was signed (June 17, 1925) entered into force (February 8, 1928) and ratified by different countries on different days, prohibits the use of such weapons and recognizes the significance of bringing together controls on chemical and biological weapons, but it does not prohibit the production, development, and stockpiling of such weapons. Therefore, these gaps had to be covered by later treaties as in the 1972 Biological and Toxin Weapons Convention and the 1993 Chemical Weapons Convention; $\boldsymbol{C}$. http://www.opcw.org/.

${ }^{7}$ The full name of the Convention is: "Convention (IV) Respecting the Laws and Customs of War on Land and its Annex: Regulations Concerning the Laws and Customs of War on Land”, which was issued on 18 October 1907 in the Hague Conference; $C \boldsymbol{f}$. http://www.unhcr.org/refworld/publisher,HAGUE,,,4374cae64,0.html.

${ }^{8}$ The Convention against Torture and Other Cruel, Inhuman or Degrading Treatment or Punishment was adopted and opened for signature, ratification and accession by the UN General Assembly on (10 December 1984) and entered into force by (26 June 1987),

http://www2.ohchr.org/english/law/cat.htm.
} 
Covenant on Civil and Political Rights of $1976^{9}$, and articles 1, 2, 3, 5, 6, 15, 17 of the Universal Declaration of Human Rights of $1948^{10}$.

Secondly, Crimes committed against the neighboring countries and their people in a way that around one million soldiers and civilians killed during Iraq-Iran war. Iraq made extensive use of chemical weapons (CW) during Iran-Iraq War of 1980-1988 ${ }^{11}$. All along, in 1988, Iraq mounted a massive chemical attack against the Kurdish town of Halabja, killing approximately 5000 civilians and injured over than 10,000, most of them were women and children.

In this respect, Article 2 of "the 1949 United Nations Convention on the Prevention and Punishment of the Crime of Genocide" defines Genocide as any acts of: "1) Killing members of the group; 2) Causing serious bodily or mental harm to members of the group; 3) Deliberately inflicting on the group conditions of life calculated to bring about its physical destruction in whole or in part; 4) Imposing measures intended to prevent births within the group; and 5) Forcibly transferring children of the group to another group". And, according to Article 3 of the same Convention, the following acts are punishable: "1) Genocide; 2) Conspiracy to commit genocide; 3) Direct and public incitement to commit genocide; 4) Attempt to commit genocide; and 5) Complicity in genocide"12.

With regard to the status of women during this period, it is clear that there was a large variation in the legal protection between the sexes in the Iraqi Legislation. For example, according to the Iraqi Personal Status Law of 1959, women (even she might be a university professor) were prevented from traveling abroad without the companion of her husband or a mahram. Women's rights were disregarded in many other laws and regulations, including the Iraqi Civil Law of 1951, Iraqi Penal Code No. 111 of 1969; also in the public Service Act and the Law of the judicial Institute. Always, like other Iraqi individuals, women had also suffered from torture and ill-treatment. In its 2001 report, the Amnesty International refers to the vulnerability of women to torture and ill-treatment and extrajudicial executions (Al-Fadhal, 2004: 159).

There have been significant legal and political developments in Iraq after the fall of the former Iraqi regime in April 9, 2003; especially after the dissolution of institutions of Ba'ath ruling party, including Army, Intelligence, and Security Police. These developments followed by the establishment of a democratic government that supposed to respect human dignity and protect citizen rights and freedoms; to the effect that the collapse of previous regime brought a good opportunity to redefine the relationship between the citizens and the state that witnessed dramatic changes towards a better citizens' legal status as a great transformation in favor of the citizens' rights and freedoms (Hussein, 2010). In the first step the Interim Governing Council was selected by which the State Administration Law for Transitional Period, called “Temporal Administrative Law” (TAL) was issued in 2004 that found certain bases in the Iraqi Permanent Constitution. Then, in the second step a democratic elections was carried out to choose 250 members of the Iraqi National Assembly that acted under the Interim Constitution (TAL) and drafted a new constitution in 2005 as the Permanent Constitution of the Federal Republic of Iraq ${ }^{13}$.

\section{Human Rights Issues in the Current Iraqi Permanent Constitution}

The Permanent Constitution of the Federal Republic of Iraq that was approved by an official referendum con-

\footnotetext{
${ }^{9}$ The International Covenant on Civil and Political Rights was adopted and opened for signature, ratification and accession by the UN General Assembly on (16 December 1966) and entered into force by (23 March 1976), http://www2.ohchr.org/english/law/ccpr.htm.

${ }^{10}$ The Universal Declaration of Human Rights, which is generally agreed to be the foundation of International Human Rights Law, has inspired a rich body of legally binding International Human Rights Treaties. The UN General Assembly proclaims this Declaration as a common standard of achievement for all peoples and all nations, to the end that every individual and every organ of society, keeping this Declaration constantly in mind, shall strive by teaching and education to promote respect for these rights and freedoms and by progressive measures, national and international, to secure their universal and effective recognition and observance, both among the peoples of Member States themselves and among the peoples of territories under their jurisdiction, http://www.un.org/en/documents/udhr/index.shtml.

${ }^{11} \boldsymbol{C f}$. http://www.nti.org/country-profiles/iraq/.

${ }^{12}$ This Convention, which was adopted by the Resolution No. 260 (III, A) of the United Nations General Assembly on 9 December 1948, entered into force by December $12^{\text {th }}, 1951$, available at: http://www.hrweb.org/legal/genocide.html. $\boldsymbol{C}$ f. also Articles (6: Genocide), and (7: Crimes against Humanity) of the "Rome Statute of the International Criminal Court", Available at: http://www.preventgenocide.org/law/icc/statute/part-a.htm.

${ }^{13}$ Also to be noted that the number of decrees and legal orders issued by the Coalition Provisional Authority (CPA) between 2003-2005 amounted to 127, including the laws of: 1) Political Parties and Entities; 2) the Elections; 3) the Independent Electoral Commission of Iraq; 4) Integrity Commission, Non-Governmental Organization; 5) the Iraqi Special Criminal Tribunal Specialized in Crimes against Humanity; 6) Iraqi Commission for Communication and Public Information; 7) the High Commission for De-Ba'athification; and etc. For more information see: Iraqi Legal Database, United Nation Development Program (UNDP), at: http://www.iraq-ild.org/.
} 
ducted in October 2005 has clearly considered Human Rights and public freedoms; and hence the Constitution brought about remarkable relevant developments. This constitution, through more than thirty three articles, from Article 14 to 46, Section Two, makes special provisions for Civil and Political Rights as well as Economic, Social and Cultural Freedoms ${ }^{14}$. For example, while Article 14 provides that: "Iraqis are equal before the law without discrimination based on gender, race, ethnicity, nationality, origin, color, religion, sect, belief or opinion, or economic or social status", Article 15 says that: "Every individual has the right to enjoy life, security and liberty. Deprivation or restriction of these rights is prohibited except in accordance with the law and based on a decision issued by a competent judicial authority". Meanwhile, Article 16 deals with the equal opportunities to be guaranteed for all Iraqis and thus the state shall take necessary measures to achieve such equal opportunities; whereas Article 18 addresses issues of citizenship and nationality that: "An Iraqi citizen by birth may not have his citizenship withdrawn for any reason. Any person who had citizenship withdrawn shall have the right to demand its reinstatement. This shall be regulated by a law".

Regarding Economic, Social and Cultural Freedoms, Article 22 of the Constitution states that: "First: Work is a right for all Iraqis in a way that guarantees a dignified life for them". "Second: The law shall regulate the relationship between employees and employers on economic basis and while observing the rules of social justice". And, "Third: The State guarantees the right to form and join unions and professional associations, and this shall be regulated by law". According to paragraph 4 of Article 29, the Constitution prohibits all form of violence and abuse in the family, school, and society. And about education as a right of people, the Constitution, in its Article 34, stipulates that: "First, Education is a fundamental factor for the progress of society and is a right guaranteed by the state. Primary education is mandatory and the state guarantees that shall combat illiteracy; Second, Free education is a right for all Iraqis; Third, the state shall encourage scientific research for peaceful purposes that serve humanity and shall support excellence, creativity, invention and different aspects of ingenuity; and Fourth, Private and public education is guaranteed, and this shall be regulated by law". It is worth mentioning that the Constitution has also taken into consideration Public Freedoms that often require legal regulations by issuing special legislation, where the Article 38 provides for the Freedom of Expression, Press, and Assembly; and in the same way, Article 39 provides for the Freedom to Form and Join Associations and Political Parties that shall be guaranteed and regulated by law. Similarly, Article 42 states that: "Each individual shall have the freedom of thought, conscience, and belief'.

To activate and guarantee these rights, the Constitutional Legislator has added Article 46, which states: "Restricting or limiting the practice of any of the rights or liberties stipulated in this Constitution is prohibited, except by a law or on the basis of a law, and insofar as that limitation or restriction does not violate the essence of the right or freedom". In parallel to these constitutional articles and in order to ensure these rights and their applications on the ground, the Constitutional Legislator initiated in Article 102 to set up special independent constitutional bodies; namely, the High Commission for Human Rights, the Independent Electoral Commission, and the Commission on Public Integrity.

\section{Human Rights Prospects under Present Political Circumstances}

It seems from the previous section of this study that the "natural rights" and "civil liberties", made up of the major aspects of Human Rights, have been ideally (at least in principle) integrated in the Iraqi Permanent Constitution and supposed to be converted into the subsequent political process to protect individuals from their government as well as to offer facilities for the provision of such rights and liberties; so that the government would be prevented from abusing its power ${ }^{15}$. However, in reality, the actual existing current political circumstances show little implementation of the indicated ideal constitutional articles on the ground, particularly the political process has not been stabilized due to the lack of security in general and the failure of the main components of the Iraqi society (the Kurds, Shias and Sunnis) to agree on defined national goals and objectives of the country in particular.

In contrast to what has been said about such ideal constitutional articles from which each Iraqi component

\footnotetext{
${ }^{14}$ Iraqi Council of Representatives (the Parliament) Iraqi Constitution, published by Media Directorate, available at: (http://parliament.iq/manshurat/dastoreng.pdf).

${ }^{15}$ For further relating theoretical arguments, $\boldsymbol{C}$. Martin, F., Schnably, S., Wilson, R., Simon, J., and Tushnet, M. (2006) International Human Rights and Humanitarian Law: Treaties, Cases and Analysis, Cambridge University Press, Cambridge, UK; and compare what the British Philosopher John Locke (1632-1704) argues about "legitimate government" and “individuals' natural rights", as the respect for Human Rights.
} 
expects fair and equal contributions in ruling the country and benefiting from its wide range natural resources that bring a larger financial income, it seems that certain politicians and political parties intend to use the Constitution to seize power and control the major means of coercion, including the Army; instead of the "Power Sharing" principle agreed on to be the foundation for the "New Iraq". With this point of view, it can be said that the current political process holds severe difficulties that have reduced the capacity of Iraq in general and Kurdistan Region in particular towards the establishment effective procedures in favor of Human Rights issues.

Therefore, it could be concluded from the above outlined current political reality, including the mentioned disagreement between the major components of the Iraqi society, Human Rights conditions in Iraq remained in an extremely poor situation, under which clear issues of Human Rights are violated; and consequently it would be difficult for the Federal Republic of Iraq to put the constitution in its full implementation and even to advocate for Democracy and Human Rights ${ }^{16}$.

\section{Human Rights Education and the Related Official Initiatives}

As (Sergio Vieira de Mello, United Nations High Commissioner of Human Rights in 2003) says, the concept and process of Human Rights Education is not limited to teaching and learning in the classrooms, but it is also related to individuals' life and experience (United Nations, 2004). This is in addition to the fact that teaching principles of Human Rights in all stages of education shall not only alleviates the culture of violent that prevailed in many eastern and multicultural societies, including the Iraqi society at the state as well as individuals level, but also reduces extremism and terrorism of the state and individuals that shall meanwhile lead to the promotion of the spirit of tolerance, cooperation and respect for religious freedoms (Osler \& Yahya, 2012). From these prospects, it is clear that Human Rights Education has wider vital roles in empowering individuals as well as societies to be aware how to defend and respect fundamental Human Rights of all persons; men, women and children, within different nations, ethnic and religious groups in the world.

In order to activate such wider roles, which are also relevant to the role and importance of Education in general, it is imperative to direct educational policies in every country to support the related educational process that requires at least:

- Enabling schools and universities as well as their teachers to promote democratic values among yang people in the country, particularly Iraq is a multicultural society that needs special attention in this regard; and

- Enhancing legal and political aspects of Human Rights in the Iraqi and Kurdish educational systems, under which schools can safeguard both children's rights and those of teachers; where the media can monitor politicians and regularly cite Human Rights.

In this respect, and as the question of Human Rights Education in Iraq and Kurdistan Region is rather new, there are few official initiatives taken by Iraqi educational authorities to be referred to in this study. Although Kurdistan Region has started thinking of taking certain initiatives towards enhancement of Human Rights Education from early 1990s, there were no related attempts in the rest of Iraq until $2003^{17}$. Accordingly, the following short notes about Human Rights Education in Iraq and Kurdistan Region can be outlined within our final arguments of this study:

1) Inclusion of Human Rights subject in the curriculum and teaching process of basic and preparatory stages of education; and likewise in the institutions of higher education, but the latter was restricted to the Faculties of Law and Political Science only at Kurdistan universities, however the original plan was to add Human Rights subject as a separate module to the curriculum of all educational stages, including universities and higher technical institutions irrespective of their specializations;

2) Despite the fact that Human Rights subject is now taught in all schools of basic and preparatory education in Kurdistan Region, this initiative is presently facing many shortcomings, particularly the lack of specialists in the related curriculum development and methods of teaching as well as preparing teaching materials in accordance to each stages of education to the effect that the Human Rights module is considered as unimportant sub-

\footnotetext{
${ }^{16} \boldsymbol{C f}$. Human Rights Watch in its World Report of 2012 about Iraq, at: http://www.hrw.org/world-report-2012/world-report-2012-iraq; and meanwhile for additional international comparisons of relating recent trends, See the United Nations (2011) Rule of Law Indicators, Implementation Guide and Project Tools, First Edition, United Nations Publication, Department of Peacekeeping Operations (http://www.un.org/en/peacekeeping/); and Office of the High Commissioner for Human Rights (OHCHR), at: (http://www2.ohchr.org/). ${ }^{17}$ According to Dr. Audrey Osler, Professor of Education at Leeds University in UK and also at Buskerud University College, Norway, Kurdistan Region-Iraq has some examples of good practice in Human Rights Education, but education in Kurdistan should be more relevant to children and address everyday concerns; $\boldsymbol{C} \boldsymbol{f}$. http://www. araratnews.eu/nuce.php?aid=615.
} 
ject, taught by non-specialist teachers and it is now merged with other subjects at Kurdistan Universities; and

3) It seems that the Iraqi Federal Ministry of Higher Education and Scientific Research has in 2009 decided to establish certain scientific departments for teaching Human Rights at the Faculties of Law, Political Science, Art, and Education, aiming at the development of teaching and research aspects of Human Rights. In this respect, Mosul University has recently launched a special course leading to Postgraduate Diploma in Human Rights.

\section{Conclusions and Further Discussions}

As it has been shown in the previous sections of this study, it could be clearly concluded that:

Firstly, the period of 1968-2003 was characterized by the prevalent of authoritarian policies and culture of violence in the Iraqi society, where the role of civil society organizations and a free media were absent. At the same time, there were no official educational programs for Human Rights Education to elaborate the notion of Human Rights neither at universities nor at schools. In contrast, all available efforts and energies were used to glorify the leader and his irrational policies. Clearly, the Iraqi educational policy in that period did not take into consideration any Human Rights issue, and subsequently the relating authorities did not work in any way to entrench Human Rights' culture at any level of the educational system from primary and secondary stages until the university level. It seems that even the only subject of "Public Freedoms" that used to be taught at Baghdad University in the late seventies and early eighties, was canceled later on. Alternatively, there were certain alternative teaching materials to promote the Arabic nationalist culture in the minds of students and that was based on the principles and foundations of the Arab Baath Socialist Party.

Secondly, the committed crimes by the former Iraqi regime against the people of Iraq in general and the Kurdish people in particular have widely violated the content and obligations of:

1) The Iraqi Constitution of 1970 and many relating enforced Iraqi laws;

2) International Law, and Norms, as well as International Human Rights Law, including the Universal Declaration of Human Rights of 1948 and International Covenant on Civil and Political Rights of 1966;

3) International Conventions, containing "the 1949 UN Convention on the Prevention and Punishment of the Crime of Genocide”, which was also signed by Iraq on December $20^{\text {th }}$, 1959 ; and also

4) Other earlier mentioned Conventions and International Treaties.

Thirdly, these indicated crimes fall under acts of "genocide" as they were committed against humanity with intent to destroy the Kurdish national and ethnical group in the 1980s. E.g., several judgments and decisions have been taken in 2005, 2006 and 2008 respectively by the Dutch Court in The Hague, the Iraq Special Criminal Tribunal Specialized in Crimes against Humanity ${ }^{18}$, and the Iraqi Council of Representatives, through which the committed crimes against the Kurdish population in Iraq during Anfal campaigns were considered as crimes of genocide ${ }^{19}$. Meanwhile, the Swedish Parliament has in December 2012 formally approved Anfal campaigns and the bombardment of the Kurdish town of Halabja with Chemical Weapons as acts of genocide against the Kurds. Similarly, in February 2013, the British Parliament has officially recognized genocide against the people of Kurdistan-Iraq.

Fourthly, in spite of the fact that there have been significant developments in Iraq and Kurdistan Region after the fall of the former Iraqi regime, there are obvious government deficiencies in respect to Human Rights issues, including Human Rights Education, that cause clear violations of Human Rights, leading to enormous contradictions between the content of the Constitution and what is happening on the ground in the real Iraqi political life. In this regard, Sarah Leah Whitson, Middle East Director of Human Rights Watch, says: "After decades of dictatorship, occupation, and terrorism, the Iraqi people today face a government that is slipping further into authoritarianism and doing little to make them safer" ${ }^{\text {"20 }}$. The failure of the present Iraqi government to comply with the content of its current constitution could be explained due to certain related reasons; notably, the existing disadvantaged political, cultural and security situation and inter sectorial conflicts between the major Iraqi components.

\footnotetext{
${ }^{18}$ The Iraq Special Criminal Tribunal Specialized in Crimes against Humanity was established following the decree No. 48 of December $10^{\text {th }}$ 2003, which was issued by the American diplomat Mr. L. Paul Bremer who was the Administrator of the Coalition Provisional Authority of Iraq following the 2003 invasion. This special court was established to deal with the related cases to crimes against humanity (including genocide) and crimes of war as well as the crimes related to the violations of Iraqi laws and constitution committed by the former Iraq regime and its responsible key Political, Security, Inelegance and Army figures leaders.

${ }^{19}$ Cf. again (Bassiouni, M. Cherif, 2004) and (Al-Fadhal, Munther, 2004).

${ }^{20}$ Iraq: A Broken Justice System; Ten Years after Invasion, Opponents Punished, Trial Rights Ignored, January 31, 2013; Human Rights Watch, at: http://www.hrw.org/news/2013/01/31/iraq-broken-justice-system.
} 
Finally; this unfavorable situation makes the integration of Human Rights Education in the Iraqi Educational System rather difficult; and hence there would be little opportunity for the promotion of Democracy and Human Rights as well as for the enhancement of Human Rights Education. In other words, the indicated challenges have hindered the capacity of Iraq and Kurdistan Region-Iraq from building any efficient system for Human Rights to enhance Human Rights issues in general and support Human Rights Education in particular. However the situation might be different in Kurdistan Region, where certain requirements have been met, particularly in the schools and institution of the Regional Ministry of Education, which is not as same as the Regional Ministry of Higher Education and Scientific Research. Iraq and Kurdistan Region urgently need a capable and efficient system for Human Rights, through which Human Rights principles could be fully applied as the basis for living together in its multicultural society that still suffer from sectarian crisis and political instability.

\section{References}

Al-Fadhal, M. (2004). Legal Studies on the Kurdish Issue and the Future of Iraq (2nd ed., p. 80), Aras Publishing Foundation, Erbil.

Bassiouni, M. C. (2004). The Iraq Special Criminal Tribunal Specialized in Crimes against Humanity in Light of Due Process Needs (pp. 16-18). Dar Al-Shorouk, Cairo. Available in Arabic; Entitled: Al-Mahkama Al-Jina'ia Al-Iraqia Al-Mokhtasa Bil Jaraem Dhed Al-Insania Fi Dho’ Al-Dhamanat Al-Muhakama Al-Monsefa, Which Is Reprinted by the International Human Rights Law Institute at DePaul University, in 2005.

Hussein, H. A. (2010). Legal Regulations of Fundamental Rights and Liberties in the 2005 Iraqi Federal Constitution, Journal of Law and Politics, College of Law and Politics, Salahaddin University, Special Volume on Federalism, 9-46.

Osler, A., \& Yahya, C. (2012). Human Rights Education in Kurdistan-Iraq: Enabling Teachers to Contribute to Processes of Gender Equity, Democracy and Development. A Paper Presented in the 2nd Scientific World Kurdish Congress (WKC 2012) Held in October 11-15, 2012 in Erbil. Cf. also Their Paper Entitled: Challenges and Complexity in Human Rights Education Teachers' Understandings of Democratic Participation and Gender Equity in Post Conflict Kurdistan-Iraq; Education Inquiry, Vol. 4, No. 1, March 2013, pp. 189-210.

United Nations (2004). ABC Teaching Human Rights: Practical Activities for Primary and Secondary Schools. OHCHR, New York \& Geneva. 
Scientific Research Publishing (SCIRP) is one of the largest Open Access journal publishers. It is currently publishing more than 200 open access, online, peer-reviewed journals covering a wide range of academic disciplines. SCIRP serves the worldwide academic communities and contributes to the progress and application of science with its publication.

Other selected journals from SCIRP are listed as below. Submit your manuscript to us via either submit@scirp.org or Online Submission Portal.
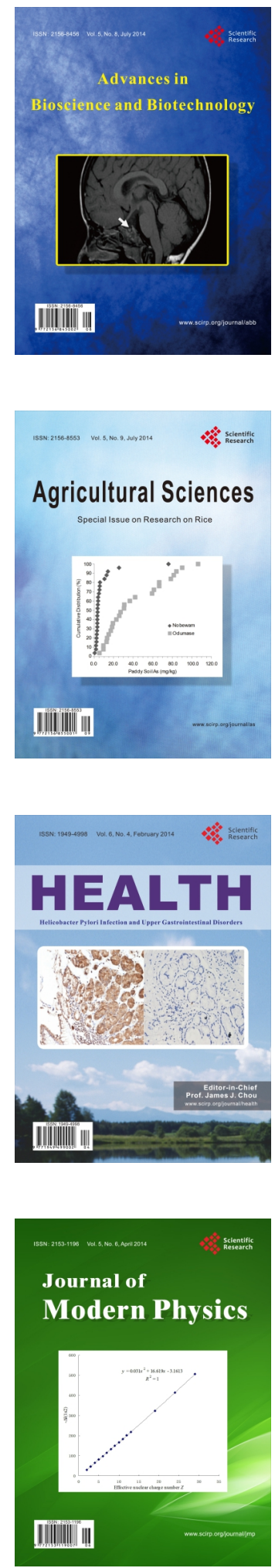
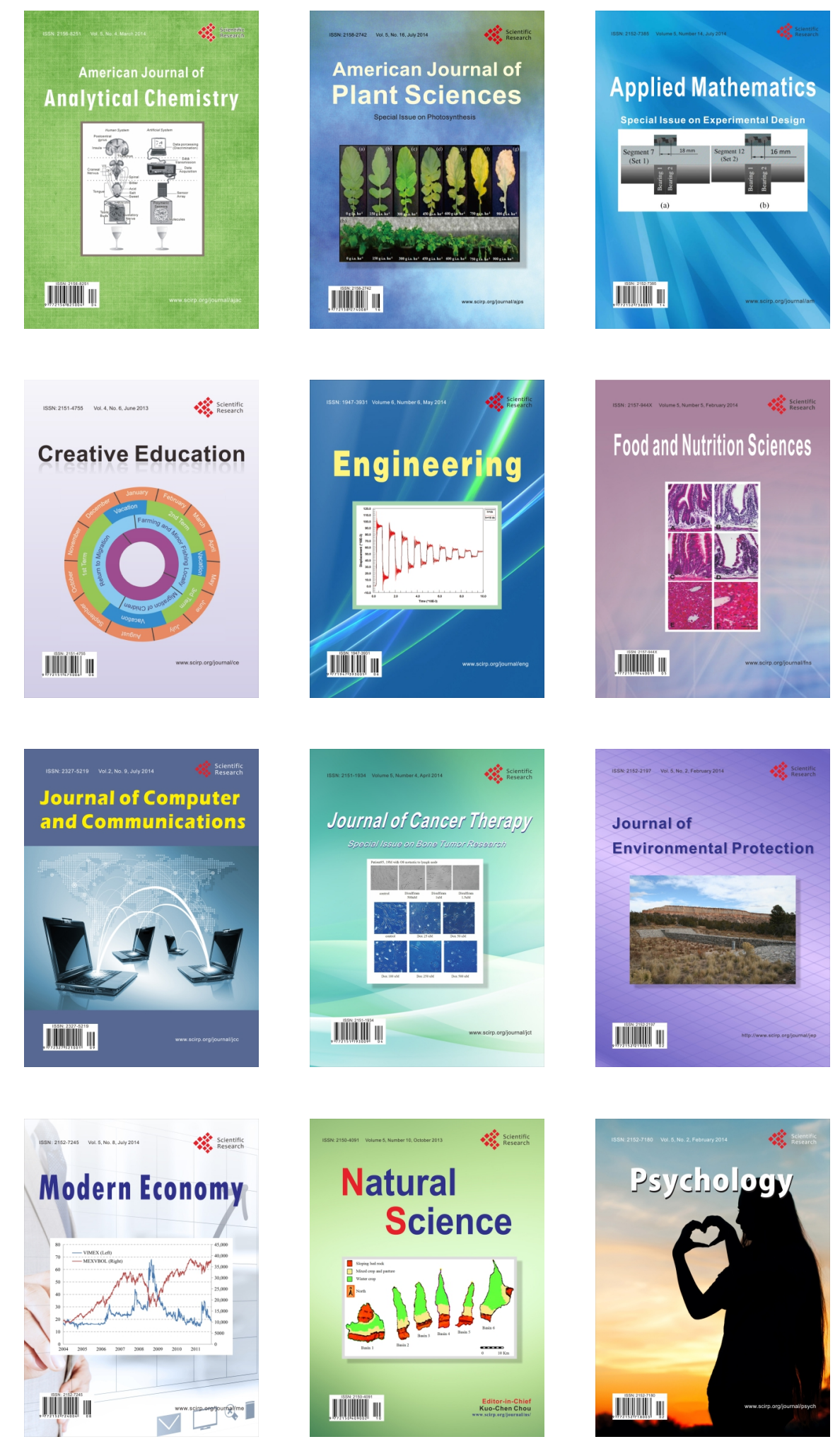